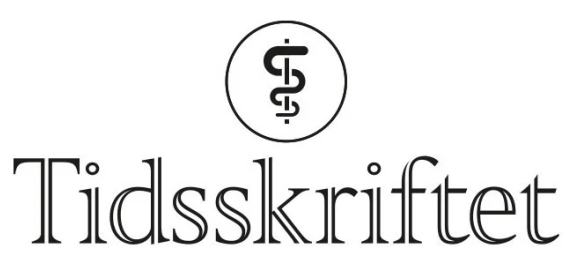

DEN NORSKE LEGEFORENING

\title{
Re: Spasmer i beina - skade i nakken
}

\author{
BREV TIL REDAKTØREN
}

\section{KJELL ARNE KVISTAD}

Kjell Arne Kvistad (f. 196o) er seksjonsoverlege på St Olavs hospital. Ingen oppgitte interessekonflikter.

Email:kjell.arne.kvistad@gmail.com

Denne interessante kasuistikken om nakkeskade (1) blir dessverre skjemmet av et uheldig figurvalg. MR-bildet som forfatterne har valgt er et T1-vektet bilde hvor man knapt kan ane spinalkanalen, og i hvert fall ikke se noen medullakompresjon. Hadde et T2-vektet bilde blitt valgt, ville informasjonsverdien vært betydelig større.

Det er uheldig at forfatterne ikke konsulterer radiolog i sitt arbeid med et slikt manuskript, og det er underlig at dette slipper gjennom Tidsskriftets redaksjonelle behandling. En annen ting er at myelopati for de fleste er en klinisk diagnose og ikke et MR-funn. MR kan vise medullakompresjon og medullaødem, men ikke myelopati.

\section{LITTERATUR}

1. Gjerde IO, Bjørk MH. Spasmer i beina - skade i nakken. Tidsskr Nor Legeforen 2014; 134: 1150. [PubMed]

Publisert: 2. september 2014. Tidsskr Nor Legeforen. DOI: 10.4045/tidsskr.14.0933

(C) Tidsskrift for Den norske legeforening 2023. Lastet ned fra tidsskriftet.no 26. april 2023. 